\title{
Chest CT Severity Score as an Auxiliary Grading Tool to COVID-19 Pneumonia Imaging Classification: A Tertiary Care Experience in Pakistan
}

\author{
Abdur Rahim Palwa ${ }^{1}$, Atiq-ur-rehman Slehria ${ }^{1}$, Bushra Nayyar ${ }^{1}$, Hafsa Aquil$^{1}$, Sidra Riaz², Uzma Nisar ${ }^{1}$ and Zaha \\ Iqbal Malik ${ }^{1}$ \\ ${ }^{1}$ Armed Forces Institute of Radiology \& Imaging, Rawalpindi, Pakistan \\ ${ }^{2}$ Department of Medicine, Pak Emirates Military Hospital, Rawalpindi, Pakistan.
}

\begin{abstract}
Objective: To identify utility of chest computed tomography severity score (CT-SS) as an additional tool to COVID-19 pneumonia imaging classification in assessing severity of COVID-19.

Study Design: Descriptive analytical study

Place and Duration of Study: Armed Forces Institute of Radiology and Imaging, (AFIRI) Rawalpindi, from April 2020 to June 2020.

Methodology: Five hundred suspected COVID-19 cases referred for high resolution computed tomography - chest were included in the study. Cases were categorised by radiological findings using COVID-19 pneumonia imaging classification, proposed in the radiological society of North America expert consensus statement on reporting chest CT findings related to COVID-19. CT-SS was calculated for all scans. Patients were clinically classified according to disease severity as per 'Diagnosis And Treatment Program of Pneumonia of New Coronavirus Infection' recommended by China's National Health Commission. The relationships between radiological findings, CT-SS, and clinical severity were explored.

Results: Based on the radiological findings, 298 cases were graded as typical, 34 as indeterminate, 15 as atypical, and 153 as negative for pneumonia. The apical and posterior basal segments of lower lobes were most commonly involved. The CT-SS showed higher values in patients of severe group as compared to those in moderate group $(p<0.05)$. CT-SS threshold for recognising severe COVID-19 was 18.5 (area under curve, 0.960 ), with $84.3 \%$ sensitivity and $92.5 \%$ specificity.

Conclusion: In coherence with COVID-19 pneumonia imaging classification, CT-SS may provide a comprehensive and objective assessment of COVID-19 severity.
\end{abstract}

Key Words: COVID-19, COVID-19 pneumonia, CT-SS, High resolution computed tomography.

How to cite this article: Palwa AR, Slehria AUR, Nayyar B, Aquil H, Riaz S, Nisar U, Malik Zl. Chest CT Severity Score as an Auxiliary Grading Tool to COVID-19 Pneumonia Imaging Classification: A Tertiary Care Experience in Pakistan. J Coll Physicians Surg Pak 2021; 31(01):14-20.

\section{INTRODUCTION}

Severe acute respiratory syndrome coronavirus-2 (SARSCoV-2) was first identified to cause a respiratory illness in Wuhan, Hubei Province, China in December $2019^{1}$, and was declared a global pandemic on 11 March 2020. ${ }^{2}$ The clinical features of COVID-19 are cough, fever, shortness of breath and fatigue. ${ }^{3}$ Treatments include combination of antiviral agents, steroids, anticoagulation and oxygen therapy, depending on disease severity.

Correspondence to: Dr. Abdur Rahim Palwa, Armed

Forces Institute of Radiology \& Imaging, Rawalpindi,

Pakistan

E-mail: arahim_palwa@hotmail.com

Received: September 28, 2020; Revised: December 26, 2020;

Accepted: January 06, 2021

DOI: https://doi.org/10.29271/jcpsp.2021.01.14
The identification of COVID-19 is primarily dependent on real-time reverse transcriptase polymerase chain reaction (RT-PCR). ${ }^{4}$ Computed tomography (CT) findings of COVID-19, their progression over time, and the interpretation of radiologists in differentiating COVID-19 from other viral infections has been studied in literature. ${ }^{5,6}$ COVID-19 demonstrates CT findings of bilateral and multi-lobar ground-glass opacities (GGO) in peripheral distribution. ${ }^{7}$ Additional imaging findings include linear, curvilinear or peri-lobular opacities, diffuse GGO and consolidation. ${ }^{8-10}$

Standardisation of COVID-19 reporting language introduced by Radiological Society of North America (RSNA) was aimed to improveradiologists' communication with physicians and to help in patient management. ${ }^{11} \mathrm{~A}$ CT severity score (CT-SS) less than 19.5 could negate severe or critical disease with high NPV of $96.3 \%$, shown by a study conducted in mainland China. Hence, CT-SS can be used as a tool for triage of patients with COVID-19. ${ }^{12}$ No study has been conducted to assess the utility of both reporting systems together. 
Table I: Clinical and demographic details of 500 Patients of COVID-19 pneumonia.

\begin{tabular}{|c|c|c|c|c|}
\hline Variables & Minimal $(n=155)$ & Moderate $(n=230)$ & Severe $(n=115)$ & p-value \\
\hline $\begin{array}{l}\text { Age } \\
\text { Mean } \pm S D \\
\text { range }\end{array}$ & $\begin{array}{c}37.90 \pm 14.255 \\
15-81\end{array}$ & $\begin{array}{c}47.77 \pm 16.147 \\
2-110\end{array}$ & $\begin{array}{c}54.76 \pm 13.995 \\
11-86\end{array}$ & $<0.001^{*}$ \\
\hline $\begin{array}{l}\text { Age group } \\
0-20 \\
21-40 \\
41-60 \\
61 \text { and above }\end{array}$ & $\begin{array}{c}10(6.5 \%) \\
91(58.7 \%) \\
40(25.8 \%) \\
14(9 \%)\end{array}$ & $\begin{array}{c}6(2.6 \%) \\
77(33.5 \%) \\
103(44.8 \%) \\
44(19.1 \%)\end{array}$ & $\begin{array}{c}1(0.9 \%) \\
16(13.9 \%) \\
62(53.9 \%) \\
36(31.3 \%)\end{array}$ & $<0.001^{*}$ \\
\hline $\begin{array}{l}\text { Gender } \\
\text { Male } \\
\text { Female }\end{array}$ & $\begin{array}{c}117(75.5 \%) \\
38(24.5 \%)\end{array}$ & $\begin{array}{c}185(80.4 \%) \\
45(19.6 \%)\end{array}$ & $\begin{array}{c}105(91.3 \%) \\
10(8.7 \%)\end{array}$ & $0.004 *$ \\
\hline $\begin{array}{l}\text { Cough } \\
\text { Yes }\end{array}$ & $68(43.9 \%)$ & $137(59.6 \%)$ & $83(72.2 \%)$ & $<0.001^{*}$ \\
\hline $\begin{array}{l}\text { Feeling cold } \\
\text { Yes }\end{array}$ & $19(12.3 \%)$ & $45(19.6 \%)$ & $24(20.9 \%)$ & 0.105 \\
\hline $\begin{array}{l}\text { Diarrhea } \\
\text { Yes }\end{array}$ & $8(5.2 \%)$ & $20(8.7 \%)$ & $10(8.7 \%)$ & 0.386 \\
\hline $\begin{array}{l}\text { Sore throat } \\
\text { Yes }\end{array}$ & $39(25.2 \%)$ & $51(22.2 \%)$ & $31(27.0 \%)$ & 0.586 \\
\hline $\begin{array}{l}\text { Body aches } \\
\text { Yes }\end{array}$ & $48(31 \%)$ & $83(36.1 \%)$ & $41(35.7 \%)$ & 0.555 \\
\hline $\begin{array}{l}\text { Headache } \\
\text { Yes }\end{array}$ & $23(14.8 \%)$ & $48(20.9 \%)$ & $22(19.1 \%)$ & 0.324 \\
\hline $\begin{array}{l}\text { Fever } \\
\text { Yes }\end{array}$ & $56(36.1 \%)$ & $115(50 \%)$ & $76(66.1 \%)$ & $<0.001^{*}$ \\
\hline $\begin{array}{l}\text { Shortness of breath } \\
\text { Yes }\end{array}$ & $24(15.5 \%)$ & $80(34.8 \%)$ & $66(57.4 \%)$ & $<0.001^{*}$ \\
\hline $\begin{array}{l}\text { Malaise } \\
\text { Yes }\end{array}$ & $26(16.8 \%)$ & $72(31.3 \%)$ & $44(38.3 \%)$ & $<0.001^{*}$ \\
\hline $\begin{array}{l}\text { Travel history } \\
\text { Yes }\end{array}$ & $17(11 \%)$ & $9(3.9 \%)$ & $4(3.5 \%)$ & $0.007 *$ \\
\hline $\begin{array}{l}\text { Travel to COVID-19 hit area } \\
\text { Yes }\end{array}$ & $18(11.6 \%)$ & $20(8.7 \%)$ & $3(2.6 \%)$ & $0.027 *$ \\
\hline $\begin{array}{l}\text { Contact history with COVID-19 Patient } \\
\text { Yes }\end{array}$ & $29(18.7 \%)$ & $28(12.2 \%)$ & $6(5.2 \%)$ & $0.004 *$ \\
\hline $\begin{array}{l}\text { Co-morbid conditions } \\
\text { Yes }\end{array}$ & $12(7.7 \%)$ & 49 (21.3\%) & $33(28.7 \%)$ & $<0.001^{*}$ \\
\hline $\begin{array}{l}\text { Diabetes mellitus } \\
\text { Yes }\end{array}$ & $6(3.9 \%)$ & $25(10.9 \%)$ & 20 (17.4\%) & $0.001 *$ \\
\hline $\begin{array}{l}\text { Hypertension } \\
\text { Yes }\end{array}$ & $4(2.6 \%)$ & 32 (13.9\%) & $21(18.3 \%)$ & $<0.001 *$ \\
\hline $\begin{array}{l}\text { Ischemic heart disease } \\
\text { Yes }\end{array}$ & $5(3.2 \%)$ & $18(7.8 \%)$ & $18(15.7 \%)$ & $0.001 *$ \\
\hline $\begin{array}{l}\text { Asthma } \\
\text { Yes }\end{array}$ & $2(1.3 \%)$ & $4(1.7 \%)$ & $1(0.9 \%)$ & 0.803 \\
\hline
\end{tabular}

The aim of this study was to establish a structured reporting system of HRCT chest for COVID-19 by using the defined guidelines of RSNA and using CT-SS to quantify the disease process. A structure focused reporting system was designed with a view to help physicians formulate appropriate management plans for patients and judiciously use limited health resources, especially respiratory support during the pandemic.

\section{METHODOLOGY}

The study was approved by Ethical Review Board of AFIRI, Rawalpindi. The first 500 cases admitted at Pak Emirates Miltary Hospital (PEMH) with clinical suspicion of COVID-19 referred to AFIRI for HRCT chest from April 2020 till June 2020 were studied. Patients with tuberculosis, lung neoplasm or history of lung surgery were excluded from the study.

Table II: Score collation of each lung region involved in moderate and severe groups.

\begin{tabular}{|l|c|c|c|c|c|}
\hline Variables & Sample & Moderate $(n=230)$ & Severe $(n=115)$ & p-value & KAPPA \\
\hline
\end{tabular}




\begin{tabular}{|c|c|c|c|c|c|}
\hline $\begin{array}{c}\text { Apical segment upper lobe (R) } \\
0 \\
1 \\
2\end{array}$ & $\begin{array}{c}239 \\
78 \\
28\end{array}$ & $\begin{array}{c}190(82.6 \%) \\
35(15.2 \%) \\
5(2.2 \%)\end{array}$ & $\begin{array}{l}49(42.6 \%) \\
43(37.4 \%) \\
23(20 \%)\end{array}$ & $<0.001$ & 0.881 \\
\hline $\begin{array}{c}\text { Anterior segment }(\mathrm{R}) \\
0 \\
1 \\
2\end{array}$ & $\begin{array}{c}134 \\
171 \\
40\end{array}$ & $\begin{array}{c}125(54.4 \%) \\
95(41.3 \%) \\
10(4.3 \%)\end{array}$ & $\begin{array}{c}9(7.8 \%) \\
76(66.1 \%) \\
30(26.1 \%) \\
\end{array}$ & $<0.001$ & 0.914 \\
\hline $\begin{array}{c}\text { Posterior segment (R) } \\
0 \\
1 \\
2\end{array}$ & $\begin{array}{c}125 \\
134 \\
86\end{array}$ & $\begin{array}{l}116(50.4 \%) \\
89(38.7 \%) \\
25(10.9 \%)\end{array}$ & $\begin{array}{c}9(7.8 \%) \\
45(39.1 \%) \\
61(53.0 \%)\end{array}$ & $<0.001$ & 0.918 \\
\hline $\begin{array}{c}\text { Medial segment }(\mathrm{R}) \\
0 \\
1 \\
2 \\
\end{array}$ & $\begin{array}{c}152 \\
154 \\
39\end{array}$ & $\begin{array}{c}138(60 \%) \\
83(36.1 \%) \\
9(3.9 \%)\end{array}$ & $\begin{array}{l}14(12.2 \%) \\
71(61.7 \%) \\
30(26.1 \%)\end{array}$ & $<0.001$ & 0.889 \\
\hline $\begin{array}{c}\text { Lateral segment }(\mathrm{R}) \\
0 \\
1 \\
2\end{array}$ & $\begin{array}{c}153 \\
124 \\
68\end{array}$ & $\begin{array}{c}145(63 \%) \\
71(30.9 \%) \\
14(6.1 \%)\end{array}$ & $\begin{array}{c}8(7.0 \%) \\
53(46.0 \%) \\
54(47 \%)\end{array}$ & $<0.001$ & 0.880 \\
\hline $\begin{array}{c}\text { Apical segment lower lobe (R) } \\
0 \\
1 \\
2\end{array}$ & $\begin{array}{c}81 \\
134 \\
130\end{array}$ & $\begin{array}{c}81(35.2 \%) \\
104(45.2 \%) \\
45(19.6 \%)\end{array}$ & $\begin{array}{c}0 \\
30(26.1 \%) \\
85(73.9 \%)\end{array}$ & $<0.001$ & 0.939 \\
\hline $\begin{array}{c}\text { Anterior basal segment (R) } \\
0 \\
1 \\
2\end{array}$ & $\begin{array}{c}155 \\
150 \\
40\end{array}$ & $\begin{array}{c}148(64.3 \%) \\
77(33.5 \%) \\
5(2.2 \%)\end{array}$ & $\begin{array}{c}7(6.1 \%) \\
73(63.5 \%) \\
35(30.4 \%)\end{array}$ & $<0.001$ & 0.892 \\
\hline $\begin{array}{c}\text { Medial basal segment }(\mathrm{R}) \\
0 \\
1 \\
2\end{array}$ & $\begin{array}{c}155 \\
142 \\
48\end{array}$ & $\begin{array}{c}145(63 \%) \\
77(33.5 \%) \\
8(3.5 \%)\end{array}$ & $\begin{array}{c}10(8.7 \%) \\
65(56.5 \%) \\
40(34.8 \%)\end{array}$ & $<0.001$ & 0.885 \\
\hline $\begin{array}{c}\text { Lateral basal segment }(\mathrm{R}) \\
0 \\
1 \\
2\end{array}$ & $\begin{array}{c}125 \\
121 \\
99\end{array}$ & $\begin{array}{l}122(53 \%) \\
79(34.4 \%) \\
29(12.6 \%)\end{array}$ & $\begin{array}{c}3(2.6 \%) \\
42(36.5 \%) \\
70(60.9 \%)\end{array}$ & $<0.001$ & 0.928 \\
\hline $\begin{array}{c}\text { Posterior basal segment (R) } \\
0 \\
1 \\
2 \\
\end{array}$ & $\begin{array}{c}68 \\
158 \\
119 \\
\end{array}$ & $\begin{array}{l}68(29.6 \%) \\
122(53 \%) \\
40(17.4 \%)\end{array}$ & $\begin{array}{c}0 \\
36(31.3 \%) \\
79(68.7 \%)\end{array}$ & $<0.001$ & 0.900 \\
\hline $\begin{array}{c}\text { Apical segment upper lobe (L) } \\
0 \\
1 \\
2\end{array}$ & $\begin{array}{c}246 \\
90 \\
9\end{array}$ & $\begin{array}{c}194(84.3 \%) \\
34(14.8 \%) \\
2(0.9 \%)\end{array}$ & $\begin{array}{c}52(45.2 \%) \\
56(48.7 \%) \\
7(6.1 \%)\end{array}$ & $<0.001$ & 0.799 \\
\hline $\begin{array}{c}\text { Anterior segment }(\mathrm{L}) \\
0 \\
1 \\
2\end{array}$ & $\begin{array}{c}157 \\
165 \\
23\end{array}$ & $\begin{array}{c}145(63 \%) \\
80(34.8 \%) \\
5(2.2 \%)\end{array}$ & $\begin{array}{l}12(10.4 \%) \\
85(73.9 \%) \\
18(15.7 \%)\end{array}$ & $<0.001$ & 0.884 \\
\hline $\begin{array}{c}\text { Posterior segment }(\mathrm{L}) \\
0 \\
1 \\
2 \\
\end{array}$ & $\begin{array}{c}149 \\
136 \\
60\end{array}$ & $\begin{array}{c}142(61.7 \%) \\
79(34.4 \%) \\
9(3.9 \%)\end{array}$ & $\begin{array}{c}7(6.1 \%) \\
57(49.5 \%) \\
51(44.4 \%)\end{array}$ & $<0.001$ & 0.916 \\
\hline $\begin{array}{c}\text { Superior lingular segment (L) } \\
0 \\
1 \\
2\end{array}$ & $\begin{array}{c}171 \\
125 \\
49\end{array}$ & $\begin{array}{c}153(66.5 \%) \\
68(29.6 \%) \\
9(3.9 \%)\end{array}$ & $\begin{array}{l}18(15.7 \%) \\
57(49.5 \%) \\
40(34.8 \%)\end{array}$ & $<0.001$ & 0.839 \\
\hline $\begin{array}{c}\text { Inferior-lingular segment (L) } \\
0 \\
1 \\
2\end{array}$ & $\begin{array}{c}157 \\
136 \\
52\end{array}$ & $\begin{array}{c}143(62.2 \%) \\
76(33 \%) \\
11(4.8 \%)\end{array}$ & $\begin{array}{l}14(12.2 \%) \\
60(52.2 \%) \\
41(35.6 \%)\end{array}$ & $<0.001$ & 0.852 \\
\hline $\begin{array}{c}\text { Apical segment lower lobe (L) } \\
0 \\
1 \\
2\end{array}$ & $\begin{array}{l}102 \\
132 \\
111\end{array}$ & $\begin{array}{l}97(42.2 \%) \\
96(41.7 \%) \\
37(16.1 \%)\end{array}$ & $\begin{array}{c}5(4.3 \%) \\
36(31.3 \%) \\
74(64.4 \%)\end{array}$ & $<0.001$ & 0.936 \\
\hline
\end{tabular}




\begin{tabular}{|c|c|c|c|c|c|}
\hline $\begin{array}{c}\text { Anterior basal segment (L) } \\
0 \\
1 \\
2\end{array}$ & $\begin{array}{c}169 \\
126 \\
50\end{array}$ & $\begin{array}{c}150(65.2 \%) \\
72(31.3 \%) \\
8(3.5 \%)\end{array}$ & $\begin{array}{c}19(16.5 \%) \\
54(47 \%) \\
42(36.5 \%)\end{array}$ & $<0.001$ & 0.896 \\
\hline $\begin{array}{c}\text { Medial basal segment (L) } \\
0 \\
1 \\
2\end{array}$ & $\begin{array}{c}200 \\
104 \\
41\end{array}$ & $\begin{array}{c}172(74.8 \%) \\
55(23.9 \%) \\
3(1.3 \%)\end{array}$ & $\begin{array}{c}28(24.4 \%) \\
49(42.6 \%) \\
38(33 \%)\end{array}$ & $<0.001$ & 0.866 \\
\hline $\begin{array}{c}\text { Lateral basal segment (L) } \\
0 \\
1 \\
2\end{array}$ & $\begin{array}{c}143 \\
134 \\
68\end{array}$ & $\begin{array}{c}132(57.4 \%) \\
85(36.9 \%) \\
13(5.7 \%)\end{array}$ & $\begin{array}{c}11(9.6 \%) \\
49(42.6 \%) \\
55(47.8 \%)\end{array}$ & $<0.001$ & 0.882 \\
\hline $\begin{array}{c}\text { Posterior basal segment (L) } \\
0 \\
1 \\
2\end{array}$ & $\begin{array}{c}100 \\
156 \\
89\end{array}$ & $\begin{array}{c}95(41.3 \%) \\
110(47.8 \%) \\
25(10.9 \%)\end{array}$ & $\begin{array}{c}5(4.3 \%) \\
46(40 \%) \\
64(55.7 \%)\end{array}$ & $<0.001$ & 0.902 \\
\hline Score of right lung & 345 & $5.27 \pm 4.024(0-18)$ & $13.45 \pm 3.606(6-20)$ & $<0.001$ & $0.979^{\#}$ \\
\hline Score of left lung & 345 & $4.33 \pm 3.627(0-13)$ & $12.20 \pm 4.288(2-20)$ & $<0.001$ & $0.979^{\#}$ \\
\hline Total score & 345 & $9.61 \pm 7.096(1-29)$ & $25.67 \pm 7.419(10-40)$ & $<0.001$ & $0.986^{\#}$ \\
\hline
\end{tabular}

Table III: Radiological findings in moderate and severe groups of covid-19 patients as per covid-19 pneumonia imaging classification.

\begin{tabular}{|c|c|c|c|c|}
\hline Variables & Sample $(n=345)$ & Moderate $(n=230)$ & Severe $(n=115)$ & P-value \\
\hline GGOs & 328 & $213(92.6 \%)$ & $115(100 \%)$ & 0.003* \\
\hline Consolidation & 258 & $149(64.8 \%)$ & $109(94.8 \%)$ & $<0.001 *$ \\
\hline \multicolumn{5}{|l|}{ Typical appearance } \\
\hline Crazy paving & 271 & $161(70 \%)$ & $110(95.7 \%)$ & $<0.001^{*}$ \\
\hline Reverse halo sign & 209 & $112(48.7 \%)$ & $97(84.3 \%)$ & $<0.001 *$ \\
\hline Peripheral distribution & 297 & $187(81.3 \%)$ & $110(95.7 \%)$ & $<0.001^{*}$ \\
\hline Bilateral involvement & 298 & $184(80 \%)$ & $114(99.1 \%)$ & $<0.001 *$ \\
\hline \multicolumn{5}{|l|}{ Indetereminate appearance } \\
\hline Unilateral distribution & 37 & $36(15.7 \%)$ & $1(0.9 \%)$ & $<0.001^{*}$ \\
\hline Non-specific distribution & 25 & $23(10 \%)$ & $2(1.7 \%)$ & $0.005^{*}$ \\
\hline Non-rounded distribution & 19 & $18(7.8 \%)$ & $1(0.9 \%)$ & $0.008 *$ \\
\hline Non-peripheral distribution & 10 & $10(4.3 \%)$ & 0 & 0.034* \\
\hline \multicolumn{5}{|l|}{ Atypical appearance } \\
\hline Isolated consolidation & 11 & $10(4.3 \%)$ & $1(0.9 \%)$ & 0.108 \\
\hline Pulmonary nodules & 11 & $9(3.9 \%)$ & $2(1.7 \%)$ & 0.348 \\
\hline Lung cavitation & 4 & $3(1.3 \%)$ & $1(0.9 \%)$ & $>0.999$ \\
\hline Inter lobular septal thickening & 4 & $3(1.3 \%)$ & $1(0.9 \%)$ & $>0.999$ \\
\hline Pleural effusion & 18 & $10(4.3 \%)$ & $8(7.0 \%)$ & 0.304 \\
\hline
\end{tabular}

Based on the "Diagnosis and Treatment Program of Pneumonia of New Coronavirus Infection," endorsed by China's National Health Commission to clinically classify COVID-19 $9^{13}$ patients were categorised as minimal, common, severe and critical. Minimal disease showed mild clinical changes with normal imaging. Patients classified as common had clinical symptoms and changes on chest imaging. Severe cases had Respiratory Rate more than 30 breaths per minute or resting oxygen saturation less than $93 \%$. Critical cases were those with Respiratory failure/Shock or any organ failure. Patients with minimal disease were classified as minimal, common case group as moderate, and patients with severe and critical status in severe group.

HRCT chest was conducted on a 16-slice CT scan machine (Alexion; Toshiba) in supine position in a single breath- holding period in craniocaudal direction from lung apex to dome of diaphragm. HRCT specifications included X-ray tube settings of $120 \mathrm{kVp}$ and $300 \mathrm{mAs}$; rotation time of 0.75 seconds; section thickness-1 $\mathrm{mm}$; and intersection space interval of five $\mathrm{mm}$. Reconstruction in coronal/sagittal planes and $3 \mathrm{D}$ reconstruction was performed.

All scans were reported by two consultant radiologists, having more than five years of expertise, on a standard picture archiving and diagnostic system (PACS) station at a predetermined window width of 800-1600 HU and window level of -800 to $-500 \mathrm{HU}$ for lung parenchyma.

Radiological features were graded as per RSNA expert consensus statement on reporting chest $\mathrm{CT}$ findings related to COVID-19, ${ }^{11}$ as typical, indeterminate, atypical, and 
negative for COVID-19 pneumonia. CT-SS is a modification of criterion employed to report ground-glass opacity, air trapping and interstitial opacity in patients of SARS in 2003. ${ }^{13,14}$ Both lungs contain a total of 18 bronchopulmonary segments, which are split into 20 regions. The apicoposterior segment of left upper lobe was split into apical and posterior, and anteromedial basal segment of left lower lobe was divided into anterior basal and medial basal regions. Changes in each region had specified scores of 0,1 , and 2 for $0 \%$, less than $50 \%$ and more than $50 \%$ parenchymal opacification, respectively. The CT-SS was calculated by adding all scores, with a range of $0-40$ for both lungs.

IBM SPSS version 25.0 programme was employed for statistical analysis. Mean \pm standard deviation values were used for continuous variables like age, right, left and total lung scores along with comparative analysis by one-way ANOVA and independent sample t-test and percentages were used for nominal variables like gender and clinical symptoms. Patterns and scores of HRCT findings in moderate and severe groups were compared using Chi-square test and Fisher's exact test. Weighted Kappa coefficient was utilised to assess the uniformity of lung region scoring by the two observers (values $\leq 0$ showing no consistency, $0.01-0.20$ as slight, $0.21-0.40$ as mild, $0.41-0.60$ as moderate, $0.61-0.80$ as significant, and $0.81-1.00$ as near perfect consistency). Inter-observer reliability for individual and total lung CT-SS scores was calculated using intraclass correlation coefficient [ICC] (graded as acceptable $=0.70-0.80$, good $=0.80-0.90$, excellent $=0.90-1.0$ ). A p-value less than 0.05 was taken as statistically significant. ROC curve analysis was conducted to assess area under the curve (AUC); and calculate sensitivity, specificity and threshold for discrimination of moderate from severe group.

\section{RESULTS}

Out of 500 patients, 155 (31\%) were placed in the minimal, $230(46 \%)$ in the moderate, and $115(23 \%)$ in the severe group (Table I) with respective mean ages of $37.90,47.77$ and 54.76 years $(p<0.001)$. The commonest clinical symptoms were cough $(288 / 500,57.6 \%, p<0.001)$ and fever $(247 / 500,49.4 \%, p<0.001)$. Significant association of COVID-19 patients with diabetes mellitus $(51 / 500,10.2 \%$, $p=0.001)$, hypertension $(57 / 500,11.4 \%, p<0.001)$, and ischemic heart disease $(41 / 500,8.2 \%, p=0.001)$ was noted.

The ICC for CT-SS of both lungs was found to be excellent in this study ( $n=500, I C C$ median=0.986, ICC mean=0.993). Excellent agreement was also noticed in scoring of right and left lungs (ICC median=0.979, ICC mean=0.989). The weighted Kappa for scoring of individual lung regions also demonstrated near perfect agreement between the two observers (Values ranging between 0.80-1.00). The scores calculated by one of the readers was then selected randomly for further investigation.
Overall, posterior basal segments of both lower lobes [right, $277 / 345$ (80.3\%); left, 245/345 (71.0\%)], apical segments of both lower lobes [right, 264/345 (76.5\%); left, 243/345 (70.4\%)], lateral basal segments of both lower lobes [right, 220/345(63.8\%); left, 202/345 (58.5\%)], and anterior and posterior segments of right upper lobe [anterior, 211/345 (61.1\%); posterior, $220 / 345(63.8 \%)]$ were found to be the sites most frequently involved in COVID-19 (Table II).

Statistically significant differences were noted between CTSS of moderate and severe groups in each lung segment with $p$-value less than 0.05 . Mean right lung score was 5.27 \pm 4.024 , left lung score $4.33 \pm 3.627$, and total CT-SS of both lungs was $9.61 \pm 7.096$ in the moderate group. The average right lung score was $13.45 \pm 3.606$, left lung score was $12.20 \pm 4.288$, and the total CT-SS of both lungs was found to be $25.67 \pm 7.419$ in the severe group.

Out of the total 500 cases, 298 cases were graded as typical, 34 as indeterminate, 15 as atypical, and 153 cases were negative for pneumonia. GGO was the most common radiological appearance in patients with imaging findings (328/345, 95.1\%, $p=0.003)$, followed by consolidation $(258 / 345,74.8 \%$, $p<0.001$, Table III). All findings, associated with typical appearance, demonstrated statistical significance with clinical severity $(p<0.05)$. Findings in indeterminate appearances also showed statistical significance $(p<0.05)$.

Four hundred and twenty-seven $(85.4 \%)$ cases were PCR positive, while 73 (14.6\%) were PCR negative. In terms of radiological criteria, 263/298 cases with typical appearance were PCR positive and 35 cases were PCR negative $(p<0.001)$. In cases with indeterminate appearance, 25 were PCR positive and 9 were PCR negative. Seven cases with atypical appearance were PCR positive and eight were negative. In cases negative with pneumonia, 132 were PCR positive and 21 PCR negative. However, all PCR negative cases with typical appearance later came out PCR positive on repeat RT-PCR testing.

In correlating with clinical criteria, 134 (86.5\%) cases from minimal, 190 (82.6\%) from moderate, and 103 (89.6\%) cases out of severe group were PCR positive, while 21 (13.5\%), 40 $(17.4 \%)$ and 12 (10.4\%) cases from minimal, moderate and severe groups, respectively, were PCR negative.

ROC curve analysis was performed for severity scoring to assess its ability to differentiate severe from minimal and moderate groups. AUC for identifying clinical severity was found to be $0.960(95 \% \mathrm{Cl}, 0.945-0.974)$. The ideal CT-SS cut off for recognising cases in severe group was 18.5 , showing $84.3 \%$ sensitivity and $92.5 \%$ specificity. Cases having CT-SS more than 18.5 were 97 in severe group and 29 in moderate group. Cases having CT-SS lower than 18.5 were 18, 201 and 155 in severe, moderate and minimal groups, respectively. It showed a positive predictive value (PPV) of $77 \%$ and a negative predictive value (NPV) of $95.2 \%$ for severe group.

\section{DISCUSSION}


COVID-19 manifests with respiratory symptoms of variable severity, depending on which patients may require variable degrees and types of organ supports. The pandemic took heavy tolls on the healthcare systems worldwide, asking for accurate assessment of disease severity so that physicians can do the maximum for the most patients. Imaging has been considered to complement clinical evaluation and laboratory parameters in therapeutic care of COVID-19. Reduced availability of the diagnostic nucleic acid kits ${ }^{15}$ and the relative insensitivity of chest radiographs in early disease led to chest $\mathrm{CT}$ becoming the primary radiological modality for diagnosis, at least in China. ${ }^{12}$ Initially, the diagnostic accuracy of CT scan was found to vary substantially between studies secondary to bias in reporting which affected generalisation of the results. ${ }^{16}$

This study was conducted to add more value to the role of radiology, especially to that of HRCT scan in COVID-19. The COVID-19 imaging classification was used to diagnose COVID-19; and applied the CT-SS to explore a relationship between HRCT findings and clinical severity of the disease. Out of 500 cases, is 298 cases (59.6\%) were graded as typical followed by 153 cases (30.6\%) negative for pneumonia, 34 $(6.8 \%)$ as indeterminate, and $15(3 \%)$ as atypical. A study in Italy also showed typical pattern to be the commonest CT finding (37.4\% cases), followed by negative cases $(26.7 \%){ }^{17}$ Atypical patterns were also found to be the least common in a study at Netherlands. ${ }^{18}$ In cases with typical appearance, the commonest pattern was GGO $(98.6 \%)$, followed by consolidation in $(83.5 \%)$ and crazy paving $(89.9 \%)$ in congruence with known imaging manifestations of COVID-19. ${ }^{19}$ The lesions were multiple and distributed symmetrically and peripherally, like findings in previous studies. ${ }^{5,20}$ The lower lobes were most frequently involved in disease process, which was congruent with previous studies. ${ }^{21}$ Another finding was disease predilection for posterior lung segments consistent with cases of SARS-CoV and MERS-CoV infections. ${ }^{22-24}$

Two hundred and sixty-three (88.3\%) cases with typical HRCT appearance were PCR positive, and 35 (11.7\%) cases were PCR negative $(p<0.001)$. In another study, percentage of RT-PCR positive cases of COVID-19 showing typical, indeterminate, atypical, and negative appearances for three readers were found to be $76.9 \%-96.6 \%, 51.2 \%-64.1 \%, 2.8 \%-5.3 \%$, and $20-25 \%$, respectively. ${ }^{18}$ In another study, typical pattern demonstrated a PPV of $87.8 \%$ for COVID-19. Atypical and negative patterns showed a PPV of $89.6 \%$ and $86.2 \%$, respectively for patients not having COVID-19. ${ }^{17}$

The ideal CT-SS cut-off for recognising cases in severe group was 18.5 , having sensitivity of $84.3 \%$ and specificity of $92.5 \%$. Cases having CT-SS more than 18.5 were 97 in severe group and 29 in moderate group. Cases having CT-SS less than 18.5 were 18, 201 and 155 in severe, moderate and minimal groups respectively, demonstrating a PPV of $77 \%$ and NPV for severe disease of $95.2 \%$. This study results were comparable to Yang et al., who established higher CT-SS in severe cases in contrast to mild cases; but used a CT-SS cut-off of 19.5 having $83.3 \%$ sensitivity and $94 \%$ specificity with NPV of $96.3 \% .{ }^{12}$ The ICC for CT-SS of both lungs was also found to be excellent in this study
( $n=500$, ICC median=0.986, ICC mean=0.993) similar to findings by Yang et al. However, this study has an added advantage of studying a significantly larger sample population (500 cases compared to 102).

This study has many limitations. First, the HRCT chest was obtained on patient's first contact with healthcare setup analysed, not directed by the duration of symptoms, which may have affected the findings. Second, it was assumed that CT-SS is a representative of the pulmonary burden of COVID-19 without any histologic confirmation. However, this data does depict that patients with higher CT-SS belonged mostly to the clinically labelled severe group. Third, CT-SS calculation of only two radiologists was assessed. Further multi-centre research is suggested to assess the effectiveness of combination of COVID-19 radiological classification with CT-SS.

\section{CONCLUSION}

CT-SS and COVID-19 imaging classification, when used together, may contribute significantly more than just the detection of COVID-19. By quantifying the pulmonary involvement, these two radiological tools may help identify patients likely to have a precarious clinical trajectory.

\section{ETHICAL APPROVAL:}

This study was conducted with the approval from the Ethics Committee of AFIRI, Rawalpindi (IERB Certificate No 13).

\section{PATIENTS' CONSENT:}

Informed consents were obtained from all patients

\section{CONFLICT OF INTEREST:}

Authors declared no conflict of interest.

\section{AUTHORS' CONTRIBUTION:}

ARP: Conception or design of the work, acquisition, analysis, interpretation of work, radiological diagnosis and drafting the work.

ARS, BN, HA, SR, UZ, ZIM: Fulfill ICJME criteria.

\section{REFERENCES}

1. Coronaviridae study group of the international committee on taxonomy of viruses (2020). The species severe acute respiratory syndrome-related coronavirus: Classifying 2019$\mathrm{nCoV}$ and naming it SARS-CoV-2. Nat Microbiol 2020; 5, 536-544. doi.org/10.1038/s41564-020-0695-z

2. WHO. Novel coronavirus - China. Feb 11, 2020. http:// www.who.int/docs/default-source/coronaviruse/situation-rep orts/ 20200211-sitrep-22-ncov.pdf?sfvrsn=fb6d49b1_2

3. Lee $\mathrm{N}$, Hui D, Wu A, Chan P, Cameron P, Joynt GM, et al. A major outbreak of severe acute respiratory syndrome in Hong Kong. N Engl J Med 2003; 348(20):1986-94. doi:10.1056/ NEJMoa030685.

4. Huang C, Wang Y, Li X, Ren L, Zhao J, Hu Y, et al. Clinical features of patients infected with 2019 novel coronavirus in Wuhan, China. Lancet 2020; 395(10223):497-506. doi:10.1016/ S0140-6736(20)30183-5.

5. Chung M, Bernheim A, Mei X, Zhang N, Huang M, Zeng X, et 
al. CT imaging features of 2019 novel coronavirus (2019-nCoV). Radiology 2020; 295(1):202-7. doi:10.1148/radiol. 2020200230.

6. Kong W, Agarwal P. Chest imaging appearance of COVID-19 infection. Radiol Cardiothorac Imaging 2020; doi: 10.1148/ ryct.2020200028.

7. Salehi S, Abedi A, Balakrishnan S, Gholamrezanezhad A. Coronavirus disease 2019 (COVID-19): A systematic review of imaging findings in 919 patients. AJR Am J Roentgenol 2020; 215(1):87-93. doi:10.2214/AJR.20.23034.

8. Franquet T. Imaging of pulmonary viral pneumonia. Radiology 2011; 260(1):18-39. doi:10.1148/radiol. 11092149.

9. Kligerman S, Raptis C, Larsen B, Henry TS, Caporale A, Tazelaar $\mathrm{H}$, et al. Radiologic, pathologic, clinical, and physiologic findings of electronic cigarette or vaping product use-associated lung injury (EVALI): Evolving knowledge and remaining questions. Radiology 2020; 294(3):491-505. doi:10.1148/radiol.2020192585.

10. Ellis SJ, Cleverley JR, Müller NL. Drug-induced lung disease: High-resolution CT findings. AJR Am J Roentgenol 2000; 175(4):1019-24. doi:10.2214/ajr.175.4.1751019.

11. Simpson S, Kay FU, Abbara S, Bhalla S, Chung JH, Chung M, et al. Radiological society of north america expert consensus statement on reporting chest $\mathrm{CT}$ findings related to COVID-19. endorsed by the society of thoracic radiology, the american college of radiology, and RSNA. Radiol Cardiothorac Imaging 2020; doi.org/10.1148/ryct.20202 00152.

12. Yang R, Li X, Liu H, Zhen $Y$, Zhang $X$, Xiong $Q$, et al. Chest CT severity score: An imaging tool for assessing severe COVID-19. Radiol Cardiothorac Imaging 2020; doi.org/ 10.1148/ryct.2020200047.

13. General office of national health commission. The diagnosis and treatment of pneumonia infected by novel coronavirus (5th Trial Edition). http://www.gov.cn/zhengce/zhengceku/ 2020-02/05/content_5474791.htm

14. Chang YC, Yu CJ, Chang SC, Galvin JR, Liu HM, Hsiao CH, et al. Pulmonary sequelae in convalescent patients after severe acute respiratory syndrome: Evaluation with thin-section CT. Radiology 2005; 236(3):1067-75. doi:10.1148/ radiol.2363040958.

15. Xiao SY, Wu Y, Liu H. Evolving status of the 2019 novel coronavirus infection: Proposal of conventional serologic assays for disease diagnosis and infection monitoring. J Med Virol 2020; 92(5):464-7. doi:10.1002/jmv.25702.

16. Suchá $D$, van Hamersvelt RW, van den Hoven AF, de Jong PA, Verkooijen HM. Suboptimal quality and high risk of bias in diagnostic test accuracy studies on chest radiography and computed tomography in the acute setting of the COVID-19 pandemic: A systematic review. Radiol Cardiothorac Imaging 2020; http://doi.org/10.1148/ ryct.2020200342.

17. Ciccarese F, Coppola F, Spinelli D, Galetta GL, Lucidi V, Paccapelo A, et al. Diagnostic accuracy of north america expert consensus statement on reporting ct findings in patients with suspected covid-19 infection: An italian single center experience. Radiol Cardiothorac Imaging 2020; doi.org/10.1148/ryct.2020200312

18. Jaegere TMH DE, , Krdzalic J, Fasen BACM, Kwee RM. Radiological society of North America chest CT classification system for reporting covid-19 pneumonia: Interobserver variability and correlation with RT-PCR. Radiol Cardiothorac Imaging 2020; http://doi.org/10.1148/ ryct.2020200213.

19. Ming-Yen NG, Lee EYP, Yang J, Yang F, Li X, Wang $\mathrm{H}$, et al. Imaging profile of the covid-19 infection: radiologic findings and literature review. Radiol Cardiothorac Imaging 202; doi.org/10.1148/ryct.2020200034.

20. Lei J, Li J, Li X, Qi X. CT imaging of the 2019 novel coronavirus (2019-nCoV) pneumonia. Radiology 2020; 295(1):18. doi:10.1148/radiol.20202002363.

21. Wu J, Wu X, Zeng W, Guo D, Fang Z, Chen L, et al. Chest CT Findings in patients with coronavirus disease 2019 and its relationship with clinical features. Invest Radiol 2020; 55(5):257-61. doi:10.1097/RLI.0000000000000670.

22. Song F, Shi N, Shan F, Zhang Z, Shen J, Lu H, et al. Emerging 2019 novel coronavirus (2019-nCoV) pneumonia. Radiology 2020; 295(1):210-217. doi:10.1148/radiol. 2020200274.

23. Wong KT, Antonio GE, Hui DS, Lee N, Yuen EH, Wu A, et al. Severe acute respiratory syndrome: radiographic appearances and pattern of progression in 138 patients. Radiology 2003; 228(2):401-406. doi:10.1148/radiol. 2282030593.

24. Ajlan AM, Ahyad RA, Jamjoom LG, Alharthy A, Madani TA. Middle East respiratory syndrome coronavirus (MERS-CoV) infection: Chest CT findings. AJR Am J Roentgenol 2014; 203(4): 782-7. doi:10.2214/AJR.14.130210. 